\title{
Feedlot-finishing lambs with different levels of soybean pre-cleaning by-product as the roughage source
}

\section{Terminação de cordeiros em confinamento com diferentes teores de coproduto de pré-limpeza de soja como fração volumosa}

Viviana Reboledo da Costa1*; Sérgio Carvalho2; Bernardo da Trindade Gallarreta3; Karoline Wagner Leal ${ }^{4}$; Juliana Milhoranza Silveira ${ }^{5}$; Mariana Dalla Favera Almeida de Oliveira5; Eduarda Alves Taschetto5; Marco Antônio Kasper ${ }^{5}$; Daniel Uliana ${ }^{5}$

\section{Highlights}

SPCB can be used without affecting lamb production performance. SPCB reduces the production cost of finishing lambs in the feedlot. SPCB can be used as a roughage source in the diet of feedlot lambs.

\begin{abstract}
An experiment was conducted in the Sheep Farming Laboratory at the Federal University of Santa Maria to examine the effect of different levels of replacement of sorghum silage with soybean pre-cleaning byproduct (SPCB) on nutrient intake, performance and feeding behavior; as well as to undertake an economic analysis of feeding finishing lambs in a feedlot system. The study involved 32 uncastrated Texel $\times$ lle de France crossbred male lambs weaned at 60 days of age. Treatments consisted of diets in which the roughage source (sorghum silage) was replaced with SPCB at the levels of $0,33.5,66.5$ or 100\% (DM basis). A 45:55 roughage:concentrate ratio was used (DM basis). The diets were composed of a roughage feed based on sorghum silage and/or SPCB, and a concentrate consisting of crushed maize, soybean meal and limestone. In addition, mineral salt was freely available to the animals. The lambs were slaughtered upon reaching the pre-established live weight of $35 \mathrm{~kg}$. Intake on a DM basis showed a quadratic response $(P \leq 0.05)$ in all forms it was evaluated and expressed, except for the NDF fraction, which increased linearly $(P \leq 0.05)$ with SPCB

Student of the Master's Course of the Postgraduate Program in Zootechnics, Federal University of Santa Maria, UFSM, Santa Maria, RS, Brazil. E-mail: totydca05@hotmail.com

2 Prof. of the Postgraduate Course in Zootechnics, UFSM, Santa Maria, RS, Brazil. E-mail: scarvalhoufsm@hotmail.com

${ }^{3}$ Student of the Doctoral Course of the Postgraduate Program in Zootechnics, UFSM, Santa Maria, RS, Brazil. E-mail: begallarreta@hotmail.com

4 Student of the Doctoral Course of the Graduate Program in Veterinary Medicine, UFSM, Santa Maria, RS, Brazil. E-mail: karolwagnerleal@gmail.com

5 Undergraduate Students in Zootechnics, UFSM, Santa Maria, RS, Brazil. E-mail: julianamilhoranza16@gmail.com; marianadallaf@gmail.com; dudataschetto@hotmail.com; marco.kasper@hotmail.com; danielvedovatouliana@ gmail.com

* Author for correspondence
\end{abstract}

Received: Sept. 03, 2020 - Approved: Dec. 09, 2020 
inclusion. Average daily weight gain was not significantly influenced $(P>0.05)$ by the different SPCB levels, averaging $292 \mathrm{~g} /$ day. As regards the feeding behavior characteristics evaluated, the number of daily feeding bouts increased linearly $(P \leq 0.01)$ with the SPCB content of the diets. Total feed cost decreased linearly $(P$ $\leq 0.01$ ), whereas the profit per kilogram of gain and profit obtained per day in the feedlot period increased linearly $(P \leq 0.01)$ with SPCB inclusion. The use of soybean pre-cleaning by-product as the roughage source in the finishing of feedlot lambs proved to be a viable alternative in both the productive and economic terms. Key words: Agro-industrial waste. Economic viability. Feeding behavior. Intake. Performance. Sheep.

\section{Resumo}

O experimento foi conduzido no Laboratório de Ovinocultura da Universidade Federal de Santa Maria, com o objetivo de avaliar o efeito de diferentes teores de substituição da silagem de sorgo por coderivado da prélimpeza de soja (CPLS), sobre o consumo de nutrientes, o desempenho e o comportamento ingestivo, assim como realizar análise econômica da alimentação na terminação de cordeiros em sistema de confinamento. Foram utilizados 32 cordeiros machos, não castrados, cruza Texel x lle de France, desmamados aos 60 dias de idade. Os tratamentos foram constituídos por diferentes teores de substituição do alimento volumoso (silagem de sorgo) por coderivado da pré-limpeza de soja em teores de $0 \%, 33,5 \%, 66,5 \%$ e $100 \%$ de substituição, com base na MS. Utilizou-se uma relação volumoso:concentrado de 45:55, com base na matéria seca. As rações eram compostas por volumoso a base de silagem de sorgo e/ou coderivados da pré-limpeza de soja, e o concentrado composto por milho desintegrado, farelo de soja e calcário calcítico. Além disso, foi fornecido sal mineral à vontade para os animais. Os cordeiros foram abatidos quando atingiram o peso pré-estabelecido de $35 \mathrm{~kg}$ de peso vivo. Os consumos em base na MS apresentaram comportamento quadrático $(P \leq 0,05)$, em todas as formas que foram avaliados e expressos, exceto 0 consumo de FDN que apresentou comportamento linear crescente $(P \leq 0,05)$ com o aumento dos teores de CPLS. O ganho de peso médio diário, não foi influenciado significativamente $(P>0,05)$ pelos diferentes teores de CPLS, com valor médio de 292 gramas por dia. Quanto às características do comportamento ingestivo avaliadas, observou-se que o número diário de refeições aumentou linearmente $(P \leq 0,01)$ com o incremento do teor de CPLS nas rações. $O$ custo total diminuiu linearmente $(P \leq 0,01)$ enquanto que 0 lucro por kg de ganho e o lucro obtido por dia no período de confinamento aumentaram linearmente $(P \leq$ $0,01)$ com a elevação da inclusão de CPLS nas rações. O uso de coderivado da pré-limpeza de soja como volumoso na terminação de cordeiros confinados, mostrou-se uma alternativa viável tanto do ponto de vista produtivo como econômico.

Palavras-chave: Comportamento ingestivo. Consumo. Desempenho. Ovinos. Resíduos agroindustriais. Viabilidade econômica.

\section{Introduction}

The demand for high-quality sheep meat has been on the rise worldwide and in Brazil, warranting increasingly productive and efficient production systems. However, the traditional sheep farming system is carried out on pasture, which entails longer production periods, greater use of field areas for the animals and less control of these animals. To intensify livestock production and provide the necessary conditions for maximum animal performance, the use of feedlots for finishing lambs is a wellestablished practice (Gomes et al., 2020). 
In this scenario, to heighten the potential of sheep meat in the market, producers should consider the system and the animal category that will provide the best animal performance. Nonetheless, the ovine species is highly demanding in nutritional terms, and one of the main strategies to meet these requirements is through feedlotting, which helps to reduce their finishing time and possibly improves their meat quality and carcass characteristics.

For the feedlot-finishing of lambs to be economically viable, some factors must be observed. These include the duration of the feedlot period; the use of by-products in the feed; the compatibility between the nutritional level and genetic potential of the animal; and the market. In addition to these variables, economic and financial management is fundamental for the project to be successful. However, actions should be aimed not only at productivity, but also at the maximum economic return for the activity to be profitable (Souza, Varga, Souza, Talamini, \& Camilo, 2014).

Diets including roughage and concentrate components have been used in the finishing of lambs in feedlots, and sorghum silage is among the traditionally used roughages. Producing this roughage does, however, require the use of areas, cultural treatments, labor, machinery and inputs, all of which increase the cost of production. Moreover, climatic problems may arise, which can reduce the yield and nutritional quality of the produced silage (Cattelam et al., 2018).

A favorable option in view of these circumstances is the use of agricultural byproducts, whicharegeneratedinlargequantities and often harmful to the environment. One of them is the soybean pre-cleaning by-product (SPCB), which results from the cleaning of the soybean grain. This waste has highly variable nutritional characteristics depending on the method of production and harvest. Despite the limited number of studies investigating this byproduct, it can be characterized as a roughage due to its high fiber content. This property is favorable for production and to producers, because in addition to eliminating the need for using large grazing areas or sorghum plantations and all processes implied, SPCB is obtained at a low cost.

Therefore, this experiment was conducted to examine nutrient intake, animal performance and behavior as well as undertake an economic analysis of the use of different levels of SPCB replacing sorghum silage in the diet of feedlot lambs.

\section{Material and Methods}

The study was carried out in the Sheep Farming Laboratory at the Department of Animal Science at the Federal University of Santa Maria (UFSM). Chemical analyses were performed in the Laboratory of Food Chemistry and Ruminant Nutrition at UFSM. The experiment was approved by the Animal Use Ethics Committee (CEUA) of the Federal University of Santa Maria (approval no. 9650290419), and all procedures followed the recommendations for animal welfare and slaughter in accordance with the Ministry's standards.

Thirty-two uncastrated male Texel $\times$ Ile de France crossbred lambs weaned at 60 days of age and dewormed and vaccinated against clostridial diseases were used. The animals were confined in individual covered stalls with slatted floors, approximately $1.0 \mathrm{~m}$ above the ground, with an area of $2 \mathrm{~m}^{2}$ per animal. All stalls 
were equipped with individual feeders and drinkers, where feed and water were provided.

The experiment was laid out in a completely randomized design with four treatments and eight replicates. Treatments consisted of diets in which sorghum silage was replaced with SPCB at different levels $(0,33.5$, 66.5 and $100 \%)$, on a dry matter (DM) basis. A 45:55 roughage:concentrate ratio was used, also on a DM basis.

Before the experimental period began, a 10-day period was allowed for the animals to acclimate to the experimental, feeding and management conditions. This period was extended until the moment when each lamb reached the pre-established weight for slaughter $(35 \mathrm{~kg})$. The lambs were weighed at the beginning and end of the experimental phase, after a 14-h solid fast. To better monitor their performance, the lambs were also weighed every 14 days.

Feed was supplied ad libitum. The diets consisted of a roughage source based on sorghum silage and/or SPCB and a concentrate composed of crushed maize, soybean meal and limestone. Mineral salt was also freely available in individual troughs. The composition of the salt was $145 \mathrm{~g}$ calcium, $65 \mathrm{~g}$ phosphorus, 18 $\mathrm{g}$ sulfur, $7 \mathrm{~g}$ magnesium, $125 \mathrm{~g}$ sodium, 80 ppm iodine, 1400 ppm manganese, 20 ppm selenium, 4000 ppm zinc, 60 ppm copper and 100 ppm molybdenum.

All diets were formulated to be isoproteic, in accordance with the Nacional Research Council [NRC] (2007), to provide a daily weight gain of $200 \mathrm{~g}$. The ratio between sorghum silage and SPCB varied according to the treatment $D M$, to achieve the desired byproduct content intended for the experimental diet.

The SPCB used in the experiment was obtained from the CAMNPAL cooperative, located at BR 158, km 297- Val de Serra - Júlio de Castilhos, RS, Brazil, consisting of the material retained in the $9-\mathrm{mm}$ sieve. To determine the physical composition of the SPCB used, a sample of $200 \mathrm{~g}$ was homogenized and manually separated into five components: stems, pods, soybean hulls, soybean grains and invasive seeds and others (percentages shown in Table 1).

Table 1

Physical composition of soybean pre-cleaning by-product

\begin{tabular}{cc|}
\hline COMPONENT & PROPORTION (\%) \\
Stems & 15.66 \\
Pods & 44.54 \\
Soybean hulls & 13.04 \\
Whole soybean grains & 3.26 \\
Powder & 12.92 \\
Invasive seeds and others & 10.58
\end{tabular}


Throughout the experiment period, feed was provided twice daily in the morning (08h00), and afternoon (17h00) to allow the maximum voluntary intake potential of the animals. The amount supplied was adjusted based on the orts from the previous day, allowing for approximately $15 \%$ daily orts.

Samples of feed and orts were collected every three days and stored in labeled plastic bags, which were then frozen at $-20{ }^{\circ} \mathrm{C}$ for laboratory analyses.

For the chemical analysis of feed and orts samples, these were pre-dried in a forced-air oven at $55 \pm 5{ }^{\circ} \mathrm{C}$ for approximately $72 \mathrm{~h}$ and subsequently ground in a Wiley mill with a 2-mm sieve. The DM contents were determined by oven-drying at $105^{\circ} \mathrm{C}$ for $24 \mathrm{~h}$ and ash was determined by incineration in a muffle at $550{ }^{\circ} \mathrm{C}$ for 2 h (D. J. Silva \& Queiroz, 2002). Neutral detergent fiber (NDF) and acid detergent fiber (ADF) were obtained according to the methodology described by Senger et al. (2008). Lignin, cellulose and hemicellulose were determined following the methodology described by D. J. Silva and Queiroz (2002). The total nitrogen $(\mathrm{N})$ content was measured by the Kjeldahl method (método 973.13, AOAC 1997) modified by Kozloski et al. (2003). For the conversion of $\mathrm{N}$ values into crude protein (CP), the correction factor of 6.25 was employed. Ether extract (EE) levels were determined in an ether reflux system (Soxtherm, Gerhardt,
Germany) at $180^{\circ} \mathrm{C}$ for $2 \mathrm{~h}$. Total carbohydrate (TC) levels were calculated according to Sniffen, O'connor, Van Soest, Fox and Russell (1992), as follows: TC (\%) $=100-(\%$ CP +\% $\mathrm{EE}+\%$ ash). Non-fibrous carbohydrates (NFC) were calculated as TC - NDF.

Table 2 shows the chemical composition of the feedstuffs that make up the experimental diets (DM basis) and Table 3 describes the proportion of the ingredients and the chemical composition of the experimental diets.

Feed intake was calculated as the difference between the amount of feed supplied and the orts (DM basis). The daily intakes of $\mathrm{DM}$, organic matter (OM), CP, EE, NDF, ADF, TC, non-fiber carbohydrates (NFC) and total digestible nutrients (TDN) were determined.

As the animals reached the preestablished weight for slaughter $(35 \mathrm{~kg}$, i.e., $60 \%$ of the adult weight of their mothers), they were weighed unfasted, which corresponded to the 'farm live weight' (FLW). Afterwards, they were subjected to a solid fast for $14 \mathrm{~h}$, after which time they were weighed again to obtain slaughter weight (SW). Next, the fasting-break index was calculated as the difference between FLW and SW. At that time, the animals were evaluated for conformation and body condition score, following the procedures described by Osório, Sañudo and Osório (1998). 
Table 2

Mean contents of dry matter (DM), organic matter (OM), crude protein (CP), ether extract (EE), neutral detergent fiber (NDF), acid detergent fiber (ADF), cellulose (CEL), hemicellulose (HEM), lignin (ADL), total carbohydrates (TC), non-fiber carbohydrates (NFC), total digestible nutrients (TDN), ash, calcium (Ca) phosphorus $(\mathrm{P})$, and $\mathrm{Ca} / \mathrm{P}$ ratio of the ingredients used in the formulation of experimental diets

\begin{tabular}{|cccccc|}
\hline Variable (\%) & Sorghum silage & SPCB & Broken maize & Soybean meal & Calcitic limestone \\
\hline DM & 35.45 & 88.78 & 86.86 & 88.3 & 100 \\
\hline OM & 91.44 & 90.76 & 98.72 & 93.17 & 0 \\
\hline CP & 5.83 & 9.60 & 8.87 & 49.2 & 0 \\
\hline EE & 4.54 & 2.86 & 4.92 & 1.85 & 0 \\
\hline NDF & 59.16 & 60.51 & 14.12 & 16.54 & 0 \\
\hline ADF & 36.2 & 41.66 & 2.97 & 5.69 & 0 \\
\hline CEL & 27.00 & 30.23 & Nc & Nc & 0 \\
\hline HEM & 22.96 & 18.85 & Nc & Nc & 0 \\
\hline ADL & 9.22 & 11.43 & Nc & Nc & 0 \\
\hline TC & 89.03 & 81.52 & 80.18 & 40.21 & 0 \\
\hline NFC & 21.78 & 16.52 & 71.38 & 27.91 & 0 \\
\hline TDN ${ }^{1}$ & 57.23 & 68.77 & 87.24 & 81.54 & 0 \\
\hline Ash & 8.56 & 9.24 & 1.28 & 6.83 & 0 \\
Ca & 0.34 & 0.44 & 0.02 & 0.3 & 34 \\
\hline P & 0.17 & 0.14 & 0.21 & 0.69 & 0.02 \\
\hline
\end{tabular}

$\mathrm{Nc}=$ not calculated

${ }^{1}$ Tabulated value (Valadares, Paulino, \& Magalhães, 2006). 
Table 3

Proportion of ingredients (\% DM) and chemical composition of experimental diets

\begin{tabular}{|c|c|c|c|c|}
\hline & \multicolumn{4}{|c|}{ SPCB content } \\
\hline & 0 & 33.5 & 66.5 & 100 \\
\hline \multicolumn{5}{|c|}{ Proportion of ingredients (\%DM) } \\
\hline Sorghum silage & 45.00 & 29.93 & 15.08 & 0.00 \\
\hline SPCB & 0.00 & 15.08 & 29.93 & 45.00 \\
\hline Broken maize & 25.45 & 27.05 & 28.55 & 30.07 \\
\hline Soybean meal & 28.31 & 26.87 & 25.46 & 24.03 \\
\hline Calcitic limestone & 1.24 & 1.08 & 0.99 & 0.90 \\
\hline \multicolumn{5}{|c|}{ Chemical composition (\%DM) } \\
\hline DM & 64.3 & 72.29 & 80.18 & 88.19 \\
\hline OM & 92.65 & 92.78 & 92.85 & 92.92 \\
\hline $\mathrm{CP}$ & 18.81 & 18.81 & 18.81 & 18.81 \\
\hline $\mathrm{EE}$ & 3.82 & 3.62 & 3.42 & 3.21 \\
\hline NDF & 34.9 & 35.09 & 35.27 & 35.45 \\
\hline ADF & 18.66 & 19.45 & 20.22 & 21.01 \\
\hline $\mathrm{TC}$ & 71.26 & 71.43 & 71.61 & 71.80 \\
\hline NFC & 36.36 & 36.34 & 36.34 & 36.35 \\
\hline TDN & 71.04 & 73.00 & 74.87 & 76.77 \\
\hline Ash & 6.11 & 6.14 & 6.16 & 6.18 \\
\hline $\mathrm{Ca}$ & 0.66 & 0.62 & 0.60 & 0.58 \\
\hline P & 0.33 & 0.31 & 0.30 & 0.29 \\
\hline Ca:P ratio & $2: 1$ & $2: 1$ & $2: 1$ & $2: 1$ \\
\hline
\end{tabular}

During the feedlot period, the animals had their feeding behavior observed for a period of $24 \mathrm{~h}$, starting at eight in the morning and ending at eight in the morning of the next day. During this evaluation period, the animals were observed, at 10-minute intervals, regarding the times spent feeding, ruminating, idle and performing other activities, as well as the time they remained standing or lying down. The number and time of feeding and rumination bouts performed per animal were also determined. The nocturnal observation was carried out using artificial lighting through incandescent lamps.
For the economic analysis, the average market values (in Brazilian Reais, BRL) at the time and in the region of the study were considered for the components of the diet and price of the lamb LW, namely, maize grain - BRL 0.59/kg; soybean meal - BRL 1.38/kg; calcitic limestone - BRL 0.19/kg; mineral salt for sheep - BRL 3.2/kg (AgroBella, 2018); and SPCB BRL 0.15/kg (Cooperativa Agricola Mista Nova Palma [CAMNPAL], 2018). The lamb price adopted was BRL 5.80/kg LW (Conexão Rural, 2019), and the price of silage was BRL 0.26/ kg (as-is basis) (Anuário da Pecuária Brasileira [ANUALPEC], 2018). 
In the economic analysis, the cost per kilogram of feed fresh matter (CKGFM) was considered. The cost of feed per day (CFD) was calculated by multiplying CKGFM by the daily amount of feed supplied. To calculate the total feed cost (TFC), CFD was multiplied by the number of days the animal spent in the feedlot, and to calculate the revenue from the sale of LW gained during the feedlot period (RLW), body weight gain (WGF) was multiplied by the amount paid per live kilogram of lamb.

The profit obtained relative to the lamb LW gained during the feedlot period (PLWF) was calculated as RLW minus TFC. Profit per kilogram of gain in feedlot (PKGF) was obtained as PLWF divided by WGF. The daily profit obtained per lamb in the feedlot period (PPD) was determined as PLWF divided by the number of days spent in the feedlot.

The experiment was laid out in a completely randomized design where eight replicates were used to evaluate the four treatments. After data collection, results were subjected to analysis of variance and regression. The equations were selected based on the coefficients of determination and the significance of the regression coefficients, adopting the $5 \%$ error probability level and using the test.

\section{Results and Discussion}

In the evaluation of the intake of dietary nutrients (expressed in $\mathrm{kg}$ day $^{-1}, \% \mathrm{LW}$ and kg LW ${ }^{0.75-1}$ ) (Table 4), practically all analyzed variables (i.e. DM, OM, CP, EE, ADF, TC and NFC) responded quadratically $(P \leq 0.05)$ to the SPCB levels.

The quadratic behavior of DM intake may be because SPCB had a slightly higher NDF content than sorghum silage. This possibly limited intake as the by-product content was increased, considering that, in being indigestible to ruminants, this fraction likely increased rumen fill, causing intake to be physically limited. Feedstuffs with high fiber contents can restrict intake due to rumen fill, which suggests the existence of a physical limit for ingestion of the by-product. This statement is supported by Sá, Borges, Macedo, Neiva and Sousa (2015), who experimented with different levels of babassu endocarp meal in sheep and observed a limitation in intake due to the high NDF and lignin contents of the by-product. In this respect, the authors emphasized the importance of fiber for the regulation of intake and nutrient availability. 
Table 4

Average intake, in $\mathrm{kg} \mathrm{day}^{-1}, \%$ live weight and metabolic weight (MW), of dry matter (DM), organic matter $(O M)$, crude protein (CP), ether extract (EE), neutral detergent fiber (NDF), acid detergent fiber (ADF), total carbohydrates (TC), non-fiber carbohydrates (NFC) and total digestible nutrients (TDN), according to the treatments

\begin{tabular}{|c|c|c|c|c|c|c|c|}
\hline \multirow{2}{*}{ Intake } & \multicolumn{4}{|c|}{$\mathrm{SPCB}^{1}$} & \multirow[b]{2}{*}{ RE } & \multirow[b]{2}{*}{ CV (\%) } & \multirow[b]{2}{*}{$P>F$} \\
\hline & 0 & 33.5 & 66.5 & 100 & & & \\
\hline DM (kg day $\left.{ }^{-1}\right)$ & 1.030 & 1.274 & 1.230 & 1.063 & 1 & 16.81 & 0.0062 \\
\hline OM (kg day $\left.{ }^{-1}\right)$ & 0.955 & 1.184 & 1.145 & 0.990 & 2 & 16.79 & 0.0064 \\
\hline $\mathrm{CP}\left(\mathrm{kg} \mathrm{day}^{-1}\right)$ & 0.213 & 0.261 & 0.251 & 0.227 & 3 & 16.04 & 0.0138 \\
\hline $\mathrm{EE}\left(\mathrm{kg} \mathrm{day}^{-1}\right)$ & 0.042 & 0.048 & 0.044 & 0.035 & 4 & 16.87 & 0.0088 \\
\hline NDF $\left(k\right.$ day $\left.{ }^{-1}\right)$ & 0.309 & 0.397 & 0.495 & 0.454 & 5 & 18.24 & 0.0001 \\
\hline ADF $\left(k\right.$ day $\left.^{-1}\right)$ & 0.158 & 0.212 & 0.173 & 0.132 & 6 & 22.11 & 0.0014 \\
\hline TC $\left(\mathrm{kg} \mathrm{day}^{-1}\right)$ & 0.717 & 0.895 & 0.866 & 0.746 & 7 & 16.99 & 0.0052 \\
\hline NFC (kg day $\left.{ }^{-1}\right)$ & 0.410 & 0.495 & 0.482 & 0.432 & 8 & 16.13 & 0.0159 \\
\hline TDN (kg day ${ }^{-1}$ ) & 0.824 & 0.923 & 1.058 & 0.998 & 9 & 15.77 & 0.0094 \\
\hline DM (\%) & 3.86 & 4.51 & 4.41 & 3.75 & 1 & 15.19 & 0.0072 \\
\hline OM (\%) & 3.58 & 4.19 & 4.11 & 3.49 & 2 & 15.15 & 0.0068 \\
\hline CP (\%) & 0.80 & 0.92 & 0.90 & 0.80 & 3 & 14.77 & 0.0208 \\
\hline EE (\%) & 0.16 & 0.17 & 0.16 & 0.13 & 4 & 15.70 & 0.0173 \\
\hline NDF (\%) & 1.16 & 1.43 & 1.77 & 1.59 & 5 & 17.26 & 0.0004 \\
\hline ADF (\%) & 0.59 & 0.77 & 0.64 & 0.47 & 6 & 20.03 & 0.0005 \\
\hline TC (\%) & 2.70 & 3.17 & 3.12 & 2.63 & 7 & 15.51 & 0.0066 \\
\hline NFC (\%) & 0.16 & 0.21 & 0.17 & 0.13 & 8 & 22.11 & 0.0014 \\
\hline TDN (\%) & 3.12 & 3.27 & 3.79 & 3.48 & $\bar{y}=3.42$ & 15.17 & 0.056 \\
\hline DM (MW) & 87.67 & 103.29 & 101.18 & 86.66 & 1 & 15.56 & 0.0072 \\
\hline OM (MW) & 81.27 & 96.60 & 94.16 & 80.69 & 2 & 15.52 & 0.0068 \\
\hline CP (MW) & 18.12 & 21.15 & 20.65 & 18.36 & 3 & 14.74 & 0.0160 \\
\hline EE (MW) & 3.59 & 3.88 & 3.67 & 2.89 & 4 & 15.63 & 0.0122 \\
\hline NDF (MW) & 26.43 & 32.83 & 40.69 & 36.52 & 5 & 17.42 & 0.0003 \\
\hline $\mathrm{ADF}(\mathrm{MW})$ & 13.55 & 17.65 & 14.49 & 10.85 & 6 & 20.66 & 0.0010 \\
\hline TC (MW) & 61.16 & 73.15 & 71.33 & 60.84 & 7 & 15.89 & 0.0064 \\
\hline NFC (MW) & 34.83 & 40.10 & 39.84 & 35.09 & 8 & 16.02 & 0.0176 \\
\hline TDN (MW) & 70.62 & 75.36 & 87.05 & 80.11 & 9 & 14.94 & 0.0363 \\
\hline
\end{tabular}

${ }^{1} \mathrm{SPCB}=$ level of replacement of dietary roughage with soybean pre-cleaning by-product.

1- $\hat{Y}=1.03840+0.00941 S P C B-0.000093 S P C B^{2} \quad R^{2}=0.24 ; \quad 2-\hat{Y}=0.96272+0.00884 S P C B-0.00008644 S P C B \quad R^{2}=0.24 ; \quad 3-\quad \hat{Y}=0.21511+0.00172 S P C B-$ $0.00001622 \mathrm{SPCB}^{2} \quad \mathrm{R}^{2}=0.21 ; \quad 4-\quad \hat{\mathrm{Y}}=0.04236+0.00025683 S P C B-0.00000116 \mathrm{SPCB}^{2} . \quad R^{2}=0.29 ; \quad 5-\quad \hat{Y}=0.33262+0.00165 S P C B . \quad R^{2}=0.41 ; \quad 6-$ $\hat{Y}=0.16262+0.00180 S P C B-0.00002152 S P C B^{2} . \quad R^{2}=0.36 ; \quad 7-\hat{Y}=0.72327+0.00688 S P C B-0.00006715 S P C B 2 . \quad R^{2}=0.25 ; \quad 8-\quad \hat{Y}=0.41314+0.00321 S P C B-$ $0.00003018 S P C B^{2} . \quad R^{2}=0.20 ; \quad 9-\quad \hat{Y}=0.85092+0.00204 S P C B . \quad R^{2}=0.21 . \quad 1-\quad \hat{Y}=3.87028+0.02820 S P C B-0.00029508 S P C B^{2} \quad R^{2}=0.23 ;$ 2- $\hat{Y}=3.58778+0.02654 S P C B-0.00027582 S P C B^{2} . R^{2}=0.24 ; 3-\hat{Y}=0.80427+0.00488 S P C B-0.00005004 S P C B 2 . R^{2}=0.18 ; 4-\hat{Y}=0.15819+0.00066608 S P C B-$

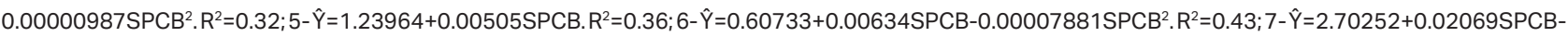

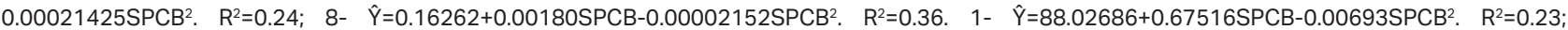
$2-\hat{Y}=81.60330+0.63464 S P C B-0.00648 S P C B^{2} . \quad R^{2}=0.23 ; \quad 3-\quad \hat{Y}=18.20104+0.12034 S P C B-0.00120 S P C B$. $R^{2}=0.19 ; \quad 4-\quad \hat{Y}=3.58723+0.0198 S P C B-$ $0.00023876 S P C B^{2} \cdot R^{2}=0.32 ; 5-\hat{Y}=28.30606+0.11850 S P C B \cdot R^{2}=0.37 ; 6-\hat{Y}=13.88479+0.14062 S P C B-0.00175 S P C B 2 . R^{2}=0.40 ; 7-\hat{Y}=61.40793+0.49697 S P C B-$ $0.00506 S_{P C B}^{2} \cdot R^{2}=0.24 ; 8-\hat{Y}=34.884648+0.226588 S P C B-0.002251 S P C B^{2} \cdot R^{2}=0.19 ; 9-\hat{Y}=72 \cdot 14801+0.12557 S P C B \cdot R^{2}=0.14$ 
Likewise, in an experiment with soybean hulls, Carvalho et al. (2015) observed a linear increase as the NDF content of the diet decreased and as the soybean hull content increased. These events explain the improvement in palatability when soybean hulls were included as well as the passage rate of soybean hulls as compared with that of sorghum silage. As another example, Wanderley et al. (2012) used silage and hay associated with spineless cactus in the diet of sheep and did not find a significant effect on DM intake, suggesting that this may have been due to the high palatability of spineless cactus and how the feed was provided. These authors pointed out that, for these reasons, the roughage effects were diluted and did not affect DM intake.

Another influencing factor is the physiological limitation of intake. Mobiglia, Camilo and Fernandes (2013) stated that animals fed high-energy diets tend to reach satiety before the rumen-reticulum capacity starts to be the limiting factor of intake. In this case, it may be that as TDN were increased, the animals increased their intake until they met their energy requirements, reducing it again thereafter. The quadratic responses seen in the intakes of CP, EE, ADF, TC and NFC are a consequence of DM intake.
The linear increase in NDF intake $(P \leq 0.05)$ as the by-product content was increased can be justified, since it accompanied the increasing NDF content of the diets that resulted from the growing percentage of the by-product (Table 3). Likewise, TDN intake also increased linearly $(P \leq 0.05)$, which may be due to the increased proportion of this nutrient in the diet as the level of replacement of sorghum silage with SPCB was increased.

In addition, EE did not influence intake, since its highest percentage in feed was $3.82 \%$, which is not limiting to feed intake by ruminants. This observation is in agreement with A. M. Silva et al. (2014), who stated that when the EE content exceeds 5 to $7 \%$ in the diet, digestive disorders and reduced intake may occur.

In the analysis of animal performance variables (Table 5), initial LW, final LW and SW did not differ significantly $(P>0.05)$, between the SPCB levels, as these variables were set at pre-established values in the experiment so as not to interfere with the results of the other variables. 
Table 5

Mean values for initial live weight (ILW), farm live weight (FLW), fasted slaughter weight (SW), fastingbreak index (FB), average daily weight gain (ADG), feed conversion (FC), conformation (CONF) and body condition score (BCS), according to the treatments

\begin{tabular}{|c|c|c|c|c|c|c|c|}
\hline & \multicolumn{4}{|c|}{ SPCB } & \multirow[b]{2}{*}{ RE } & \multirow[b]{2}{*}{$\mathrm{CV}$} & \multirow[b]{2}{*}{$P>F$} \\
\hline & 0 & 33.5 & 66.5 & 100 & & & \\
\hline ILW (kg) & 20.36 & 21.55 & 21.69 & 23.30 & $\bar{y}=21.72$ & 16.11 & 0.1300 \\
\hline FLW (kg) & 36.14 & 35.78 & 35.35 & 35.55 & $\bar{y}=35.70$ & 2.45 & 0.1203 \\
\hline SW (kg) & 33.64 & 33.26 & 32.88 & 33.12 & $\bar{y}=33.22$ & 2.17 & 0.0943 \\
\hline $\mathrm{FB}(\mathrm{kg})$ & 2.51 & 2.52 & 2.48 & 2.42 & $\bar{y}=2.48$ & 29.80 & 0.8131 \\
\hline FB (\%) & 6.90 & 7.04 & 6.98 & 6.77 & $\bar{y}=6.93$ & 28.61 & 0.9002 \\
\hline ADG $\left(\mathrm{kg} \mathrm{day}^{-1}\right)$ & 0.241 & 0.323 & 0.298 & 0.307 & $\bar{y}=0.292$ & 21.82 & 0.1013 \\
\hline FC & 4.02 & 4.00 & 3.75 & 3.47 & $\bar{y}=3.81$ & 17.40 & 0.0919 \\
\hline CONF $(1-5)^{1}$ & 2.91 & 3.09 & 3.31 & 3.07 & $\bar{y}=3.10$ & 10.58 & 0.0792 \\
\hline $\operatorname{BCS}(1-5)^{2}$ & 2.91 & 3.03 & 3.19 & 3.00 & $\bar{y}=3.03$ & 9.20 & 0.3023 \\
\hline
\end{tabular}

11 = very poor, $5=$ excellent.

21 = emaciated, 5 = obese.

Despite increasing as the SPCB inclusion level was increased, ADG did not differ significantly $(P>0.05)$, between the treatments, averaging $0.292 \mathrm{~kg} \mathrm{day}^{-1}$. This result is higher than the $0.200 \mathrm{~kg}$ day $^{-1}$ recommended by the NRC (2007) for this animal category and the $0.193 \mathrm{~kg}$ day $^{-1}$ observed by Cação et al. (2014), who used SPCB in feedlot lambs. It is also higher than the $0.260 \mathrm{~kg}$ day $^{-1}$ described by Carvalho et al. (2016), who tested the use of soybean hulls as a roughage feed in the diet of feedlot sheep.

Feed conversion did not differ significantly $(P>0.05)$ in response to the levels of replacement of the roughage source, averaging 3.8:1. This ratio is close to the 4.26:1 observed by Bernardes et al. (2015), who used high-grain feed in feedlot lambs.
The feeding behavior of the animals (Table 6) reveals that the increasing dietary inclusion of SPCB did not significantly influence $(P>0.05)$ the times spent feeding, ruminating, idle, or performing other activities, which shows that the diets perfectly suited the animals in the experiment. Sá et al. (2015) used babassu cake and also found no significant difference in feeding behavior, which can be explained by the fact that the diets were isofibrous. The values obtained in this experiment are similar to the 265.5 and 395.5 min day $^{-1}$ (feeding and rumination, respectively) obtained by Sá et al. (2015) after using babassu endocarp meal, a feedstuff high in NDF and lignin. 
Table 6

Mean values for the time spent feeding (FED), ruminating (RUM), total chewing (TCT), idle (IDL), performing other activities (OTH), standing (STD), and lying (LYN), number of feeding bouts (NFB) and number of rumination bouts (NRB), in $24 \mathrm{~h}$, and time spent per feeding bout ( $\mathrm{min} \mathrm{FB}^{-1}$ ) and per rumination bout $\left(\min \mathrm{RB}^{-1}\right)$, according to the treatments

\begin{tabular}{|c|c|c|c|c|c|c|c|}
\hline & \multicolumn{4}{|c|}{ SPCB } & \multirow[b]{2}{*}{$\mathrm{RE}$} & \multirow[b]{2}{*}{ CV (\%) } & \multirow[b]{2}{*}{$P>F$} \\
\hline & 0 & 33.5 & 66.5 & 100 & & & \\
\hline FED (min day $\left.^{-1}\right)$ & 231.25 & 237.50 & 253.75 & 278.57 & $\bar{y}=250.26$ & 21.01 & 0.0773 \\
\hline RUM (min day $\left.{ }^{-1}\right)$ & 450.00 & 426.25 & 426.25 & 394.28 & $\bar{y}=424.19$ & 12.57 & 0.0676 \\
\hline TCT (min day ${ }^{-1}$ ) & 681.25 & 663.75 & 680.00 & 672.85 & $\bar{y}=674.46$ & 9.89 & 0.8271 \\
\hline IDL $\left(\min\right.$ day $^{-1}$ ) & 698.75 & 721.25 & 727.50 & 698.57 & $\bar{y}=711.51$ & 9.41 & 0.2954 \\
\hline OTH (min day $\left.{ }^{-1}\right)$ & 68.75 & 55.00 & 57.50 & 68.57 & $\bar{y}=62.45$ & 62.24 & 0.3816 \\
\hline STD (min day $\left.{ }^{-1}\right)$ & 395.00 & 427.50 & 435.00 & 475.71 & $\bar{y}=433.30$ & 17.68 & 0.0559 \\
\hline LYN (min day ${ }^{-1}$ ) & 1040.00 & 1012.50 & 1005.00 & 964.28 & $\bar{y}=1005.44$ & 7.37 & 0.0645 \\
\hline FED (\%) & 16.06 & 16.49 & 17.62 & 19.34 & $\bar{y}=17.37$ & 21.01 & 0.0773 \\
\hline RUM (\%) & 31.25 & 29.60 & 29.60 & 27.38 & $\bar{y}=29.45$ & 12.57 & 0.0676 \\
\hline TCT (\%) & 47.31 & 46.09 & 47.22 & 46.72 & $\bar{y}=46.83$ & 9.89 & 0.8271 \\
\hline IDL (\%) & 48.52 & 50.08 & 50.52 & 48.51 & $\bar{y}=49.40$ & 9.41 & 0.2954 \\
\hline ОTH (\%) & 4.77 & 3.82 & 3.99 & 4.76 & $\bar{y}=4.33$ & 62.24 & 0.3816 \\
\hline STD (\%) & 27.43 & 29.68 & 30.20 & 33.03 & $\bar{y}=30.08$ & 17.68 & 0.0559 \\
\hline LYN (\%) & 72.22 & 70.31 & 69.79 & 66.96 & $\bar{y}=69.82$ & 7.37 & 0.0654 \\
\hline NFB & 11.62 & 10.25 & 13.00 & 15.14 & 1 & 22.76 & 0.0084 \\
\hline NRB & 23.62 & 23.00 & 22.12 & 21.86 & $\bar{y}=22.65$ & 14.97 & 0.2689 \\
\hline $\min \mathrm{FB}^{-1}$ & 19.53 & 23.76 & 19.63 & 18.75 & 2 & 15.95 & 0.0351 \\
\hline $\min \mathrm{RB}^{-1}$ & 19.49 & 18.91 & 19.39 & 18.12 & $\bar{y}=18.98$ & 15.85 & 0.4765 \\
\hline
\end{tabular}

${ }^{1} \mathrm{SPCB}=$ level of replacement of dietary roughage with soybean pre-cleaning by-product.

$1-\hat{Y}=10.52678+0.03911 S P C B . R^{2}=0.22$.

2- $\hat{Y}=20.10747+0.09661$ SPCB-0.00117SPCB ${ }^{2} . R^{2}=0.18$.

In addition, the number of feeding bouts increased linearly $(P \leq 0.05)$ with the replacement levels, possibly due to the smaller particle size and consequent higher passage rate, which caused the animals to visit the trough more often to eat. The time per feeding bout, in turn, responded quadratically ( $\mathrm{P} \leq 0.05)$. As observed, when the animals performed fewer feeding bouts, the duration of each bout was longer and vice-versa, which is possibly due to the rumen fill effect and the passage rate. Despite the lack of significant differences $(P>0.05)$, there was a downward trend for the number of rumination bouts as the by-product levels were increased.

As can be seen in Table 7, the fresh matter supply of silage and SPCB clearly showed decreasing and increasing linear responses, respectively, according to the replacement of each ingredient, while concentrate fresh matter supply increased linearly $(P \leq 0.05)$ with the SPCB content of 
the diet. As a consequence of this, the cost of concentrate per day accompanied this growing linear trend. Nonetheless, the total feed cost decreased linearly, as the cost of the by-product per kilogram is lower than that of silage, which reduced the feed cost as the levels of SPCB were increased.

Table 7

Mean values for initial live weight (ILW), slaughter weight (SW), weight gain in the feedlot period (WGF), number of days for slaughter (DAYS), silage fresh matter supply (SFMS), SPCB fresh matter supply (SPCBFMS), concentrate fresh matter supply (CFMS) cost of silage per day (CSD), cost of SPCB per day (CSPCBD), cost of concentrate per day (CCD), cost of feed per day (CFD) total feed cost (TFC), revenue from the sale of live weight (RLW), profit from live weight gained in feedlot (PLWF), profit per kilogram of gain in feedlot (PKGF) and profit per day in the feedlot period (PPD), according to the treatments

\begin{tabular}{|c|c|c|c|c|c|c|c|}
\hline & & & & & & & \\
\hline & 0 & 33.5 & 66.5 & 100 & RE & CV & $P>F$ \\
\hline ILW (kg) & 20.36 & 21.55 & 21.69 & 23.30 & $\bar{y}=21.72$ & 16.11 & 0.1300 \\
\hline SW (kg) & 33.64 & 33.26 & 32.88 & 33.12 & $\bar{y}=33.22$ & 2.17 & 0.0943 \\
\hline WGF (kg) & 13.28 & 11.71 & 11.19 & 9.83 & $\bar{y}=11.50$ & 32.92 & 0.0605 \\
\hline DAYS & 62.50 & 44.00 & 39.38 & 34.43 & 1 & 39.74 & 0.0047 \\
\hline SFMS (kg day-1) & 1.24 & 1.05 & 0.55 & 0 & 2 & 26.94 & $<0.0001$ \\
\hline SPCBFMS (kg day $\left.{ }^{-1}\right)$ & 0 & 0.21 & 0.44 & 0.68 & 3 & 15.02 & $<0.0001$ \\
\hline CFMS (kg day-1) & 0.57 & 0.73 & 0.77 & 0.79 & 4 & 16.38 & 0.0007 \\
\hline $\operatorname{CSD}\left(B R L\right.$ day $\left.^{-1}\right)$ & 0.32 & 0.27 & 0.14 & 0 & 5 & 26.94 & $<0.0001$ \\
\hline CSPCBD (BRL day-1) & 0 & 0.03 & 0.07 & 0.10 & 6 & 15.02 & $<0.0001$ \\
\hline CCD $\left(B R L\right.$ day $\left.^{-1}\right)$ & 0.49 & 0.63 & 0.65 & 0.66 & 7 & 16.72 & 0.0036 \\
\hline CFD (BRL day-1) & 0.82 & 0.93 & 0.86 & 0.76 & 8 & 16.89 & 0.0469 \\
\hline TFC (BRL) & 48.20 & 40.10 & 33.68 & 25.58 & 9 & 36.10 & 0.0020 \\
\hline RLW (BRL) & 195.08 & 192.89 & 190.68 & 192.12 & $\bar{y}=192.69$ & 2.17 & 0.1009 \\
\hline PLWF (BRL) & 146.78 & 152.8 & 156.99 & 166.58 & 10 & 8.09 & 0.0047 \\
\hline PKGF $\left(B R L \mathrm{~kg}^{-1}\right)$ & 1.90 & 2.41 & 2.85 & 3.14 & 11 & 35.08 & 0.0076 \\
\hline PPD (BRL day $\left.{ }^{-1}\right)$ & 0.51 & 0.70 & 0.85 & 0.92 & 12 & 36.65 & 0.0040 \\
\hline
\end{tabular}

${ }^{1} \mathrm{SPCB}=$ level of replacement of dietary roughage with soybean pre-cleaning by-product.

$1-\hat{Y}=58.49567-0.27024$ SPCB. $R^{2}=0.24$.

$2-\hat{Y}=1.34448-0.01260$ SPCB. $R^{2}=0.85$.

3- $\hat{Y}=-0.00882-0.00684 S P C B . R^{2}=0.97$.

4- $\hat{Y}=0.60956+0.00216$ SPCB. $R^{2}=0.33$.

$5-\hat{Y}=0.34957+0.00328 S P C B . R^{2}=0.85$.

$6-\hat{Y}=-0.00132+0.00103 S P C B . R^{2}=0.97$.

$7-\hat{Y}=0.52783+0.00049360 S P C B \cdot R^{2}=0.26$

8- $\hat{Y}=0.82429+0.00403 S P C B-0.00004780 S P C B 2 . R^{2}=0.16$.

$9-\hat{Y}=48.05225-0.22328 S P C B . R^{2}=0.28$.

$10-\hat{Y}=146.33379+0.18864$ SPCB. $R^{2}=0.25$.

$11-\hat{Y}=1.94642+0.01260$ SPCB. $R^{2}=0.22$.

$12-\hat{Y}=0.53843+0.00414 S P C B . R^{2}=0.25$. 
Another factor that influences economic analysis is the number of days spent in the feedlot, which decreased linearly $(P \leq 0.05)$ as the by-product inclusion level was increased. Therefore, with a lower feed cost and fewer days in the feedlot, the profits (PLWF, PKGF and PPD) increased linearly $(P \leq 0.05)$, as favored by the increasing content of the by-product in the diet. The average value of BRL 0.75 day $^{-1}$ obtained in this experiment was higher than the BRL 0.47 day $^{-1}$ found by Frasson (2015), who used wet brewers byproduct in feedlot sheep. Carvalho et al. (2016) used soybean hulls in the diet of feedlot sheep and obtained an average profit of BRL 0.96 per kilogram of gain in the feedlot and BRL 0.26 per day, which are lower than the respective BRL $2.58 \mathrm{~kg}^{-1}$ and BRL 0.75 day $^{-1}$ obtained in this experiment. The revenue from the sale of live weight did not differ significantly $(P>0.05)$, as it is a market value that does not vary, just as the LW of the animals between the treatments did not differ.

\section{Conclusion}

The use of by-product from soybean pre-cleaning to replace sorghum silage as a roughage feed in the diet of feedlot lambs does not change their production performance. In addition, feed costs decrease linearly as the level of replacement of sorghum silage with this by-product is increased, which in turn increases the profit obtained per animal. Therefore, the total replacement of sorghum silage with soybean pre-cleaning by-product as the roughage source in the diet of feedlot lambs can be recommended when a roughage:concentrate ratio of $45: 55$ is adopted, on a dry matter basis.

\section{References}

AgroBella (2018). Nutrição animal. Empresa fornecedora de ração. Disponível em http://www.agrobella.com

ASSOCIATION OF OFFICIAL ANALYTICAL CHEMISTS - AOAC. Official methods of analysis. (16a ed.). Washington, D. C: 1997. $1141 \mathrm{p}$.

ANUALPEC. (2018). Anuário da Pecuária Brasileira. São Paulo, SP: Instituto FNP.

Bernardes, G. M. C., Carvalho, S., Pires, C. C., Motta, J. H., Teixeira, W. S., Borges, L. I.,... Venturini, R.S. (2015). Consumo, desempenho e análise econômica da alimentação de cordeiros terminados em confinamento com o uso de dietas de alto grão. Arquivo Brasileiro de Medicina Veterinária e Zootecnia, 67(6), 1684-1692. doi: 10.1590/1678-4162-7934

Cação, M. M. F., Santos, G. B., Cavaletti, M., Bueno, M. S., Nardon, R. F., \& Pereira, J. A. (2014). Resíduo de limpeza de soja em substituição ao farelo de soja na dieta de cordeiro em terminação. Boletim de Indústria Animal, 71(2), 106-113. doi: 10.17523/bia.v71n2p106

Cooperativa Agricola Mista Nova Palma Ltda. (2018). BR 158, Km 297 Distrito de Val de Serra Júlio de Castilhos, RS. Brasil.

Carvalho, S., Dias, F. D., Pires, C. C., Wommer, T. P., Venturini, R. S., Frasson, M. F.,... Brutti, D. D. (2015). Consumo e desempenho produtivo de cordeiros das raças Texel e Ideal terminados em confinamento com dietas contendo diferentes teores de casca de soja. Semina: Ciências Agrárias, 36(3), 2131-2140. doi: 10.5433/ 1679-0359.2015v36n3Supl1p2131 
Carvalho, S., Pires, C. C., Wommer, T. P., Lopes, J. F., Mônego, C. O., \& Pilecco, V. M. (2016). Economicidade e desempenho produtivo de cordeiros confinados submetidos a dietas com resíduos agroindustriais. Ciência Animal Brasileira, 17(1), 36-44 doi: 10.1590/1089-6891v17i119806

Cattelam, J., Argenta, F. M., Alvez, D. C. Fo., Brondani, I. L., Pacheco, P. S., Pacheco, R. F., Klein, J. L. (2018). Características da carcaça e qualidade da carne de novilhos e novilhas alimentados com diferentes dietas de alto grão em confinamento. Ciências Agrárias, 39(2), 667-682. doi: 10.5433/1679-0359.2018v39n2p667

Conexão Rural (2019). Cotações. Recuperado de http://www.conexaorural.com.br/cone xoes131218.php

Frasson, M. F. (2015). Resíduo Úmido de cervejaria em substituição ao alimento volumoso na terminação de cordeiros em confinamento. Dissertação de mestrado. Santa Maria, RS, Brasil.

Gomes, H. F. B., Castro, A. A. de, Emmert, A. Q., Marques, R. O., Gonçalves, H. C., Brito, E. P. Correa, H. L. (2020). Influência da substituição do farelo de soja por grão seco de destilaria no desempenho e características de carcaça de ovinos confinados. Semina: Ciências Agrárias, 41(5), 2259-2272. doi: 10. 5433/1679-0359.2020v41n5Supl1p2259

Kozloski, G. V., Perotoni, J., Ciocca, M. L. S., Rocha, J. B. T., Raiser, A. G., \& Sanchez, L. M. B. (2003). Potencial nutritional assessment of dwarf elephant grass (Pennisetum purpureum schum. Mott) by chemical composition, digestion and net portal flux of oxygen in cattle. Animal Feed
Science and Technology, 104 (1-4), 27-40. doi: 10.1016/S0377-8401(02)00328-0

Mobiglia, A. M., Camilo, F. R., \& Fernandes, J. J. R. (2013). Comportamento ingestivo e alguns reguladores de consumo em bovinos de corte. PUBVET, 7(17), 6. doi: 10.22256/pubvet.v7n17.1585

Nacional Research Council (2007). Nutrient requirements of small ruminants: sheep, goats, cervids, and new worlds camelids. Washington, D.C: National Academy of Science.

Osório, J. C., Sañudo, C., \& Osório, M. T. (1998). Produção de carne ovina, alternativa para o Rio Grande do Sul. Pelotas: Editora Universitária/UFPel.

Sá, H. C. M., Borges, l., Macedo, G. de L., Jr., Neiva, J. N. M., \& Sousa, L. F. (2015). Farinha do endocarpo I do babaçu na formulação de dietas para ovinos. Revista Caatinga, 28(2), 207-216. Recuperado de https://periodicos.ufersa.edu.br/index. php/caatinga/article/view/4115/pdf_263

Senger, C. C. D., Kozloski, G. V., Bonnecarrere Sanchez, L. M., Mesquita, F. R., Alves, T. P., \& Castagnino, D. S. (2008). Evaluation of autoclave procedures for fiber analysis in forage and concentrate feedstuffs. Animal Feed Science and Technology, 146(1-2), 169-174. doi: 10.1016/j. anifeedsci.2007.12.008 Retrieved from https://www.sciencedirect.com/science/ article/abs/pii/S037784 0102003280

Silva, A. M., Oliveira, R. L., Ribeiro, O. L., Bagaldo, A. R., Bezerra, L. R., Carvalho, S. T.,... Leão, A. G. (2014). Valor nutricional de resíduos da agroindústria para alimentação de ruminantes. Comunicata Scientiae, 5(4), 370-379. doi: 10.14295/cs.v5i4.870 
Silva, D. J., \& Queiroz, A. C. (2002). Analise de alimentos: métodos químicos e biológicos (3a ed.). Viçosa, MG: Universidade Federal de Viçosa.

Sniffen, C. J., O'Connor, J. D., Van Soest, P. J., Fox, D. G., \& Russell, J. B. (1992) A net carbohydrate and protein system for evaluating cattle diets: II. Carbohydrate and protein availability. Journal of Animal Science, 70(11), 3562-3577. doi: 10.2527/1992.70113562x

Souza, M. R. de, Vargas, F. M. de, Jr., Souza, L. C. F. de Talamini, E., \& Camilo, F. R. (2014). Análise econômica do confinamento de cordeiros alimentados com feno de capim piatã e soja in natura ou desativada. Custos e Agronegócio online, 10(1), 131-151. Recuperado de http://www.custoseagro negocioonline.com.br/numero1v10/ Cordeiros.pdf
Valadares, S. C., F., Paulino, P. V. R., \& Magalhães, K. A. (2006). Exigências nutricionais de zebuínos e tabela de composição de alimentos BR - corte. Viçosa, MG: UFV, DZO.

Wanderley, W. L., Ferreira, M. de A., Batista, Â. M. V., Véras, A. S. C., Bispo, S. V., Silva, F. M. da, \& Santos, V. L. F. dos. (2012). Consumo, digestibilidade e parâmetros ruminais em ovinos recebendo silagens e fenos em associação à palma forrageira. Revista Brasileira de Saúde e Produção Animal, 13(2), 444-456. doi: 10.1590/S151999402012000200013. Recuperado de https://www.science direct.com/science/ article/abs/pii/S0377840102003280 